УДК 539.3

${ }^{1}$ О. Я. Григоренко, д-р фріз.-мат. наук,

${ }^{1}$ М. Ю. Борисенко, канд. фріз.-мат. наук,

${ }^{2}$ О. В. Бойчук, канд. фріз.-мат. наук, ${ }^{3}$ В. С. Новицький

\title{
ЗАСТОСУВАННЯ ЕКСПЕРИМЕНТАЛЬНОГО І ЧИСЛОВОГО МЕТОДІВ ДО ДОСЛІДЖЕННЯ ВІЛЬНИХ КОЛИВАНЬ ПРЯМОКУТНИХ ПЛАСТИН
}

Досліджуються динамічні характеристики тонкої ізотропної жорстко закріпленої квадратної пластини за допомогою реалізації некласичного експерименту Хладні та методу скінченних елементів, реалізованого на ліцензійному програмному комплексі FEMAP. Описується методика проведення експерименту i числового розрахунку. Проводиться порівняльний аналіз отриманих результатів експериментальних та числових досліджень.

Ключові слова: квадратна пластина, вільні коливання, форми коливань, експеримент Хладні, метод скінченних елементів.

Вступ. У різних галузях сучасної техніки пластини різноманітних форм $€$ найбільш поширеними елементами тонкостінних конструкцій. Для оцінки міцності і забезпечення надійного функціонування таких конструкцій та механізмів необхідно володіти інформацією про їхні динамічні характеристики, в свою чергу це вимагає розробки різних методів та підходів дослідження вільних коливань, зокрема, експериментальних, оскільки основною перевіркою будь-якого з результатів розрахунків залишається тільки фрізичний експеримент. Числовий аналіз представляє лише моделювання реальної конструкції, і від того, наскільки вдала модель і математичний апарат, який реалізує цю модель, залежить відповідність результатам експериментальної перевірки.

Метою цієї роботи $є$ визначення частот та форм вільних коливань пружної ізотропної жорстко закріпленої квадратної пластини за допомогою некласичного експерименту Хладні, а також порівняння отриманих результатів з розрахунками, виконаними методом скінченних елементів (MCE) на ліцензійному програмному засобі FEMAP з розв'язувачем NASTRAN [7].

Дослідженню коливань квадратних пластин присвячено багато різних публікацій в яких розглянуто різні підходи розв'язування поставленої задачі.

У [9] розраховані частоти квадратної пластини постійної товщини, жорстко закріпленої по краям, за допомогою чисельно-аналітичного методу сплайн-коллокації в поєднанні з методом дискретної ортогоналіза-

(С) О. Я. Григоренко, М. Ю. Борисенко,

О. В. Бойчук, В. С. Новицький, 2019 
ції, отримані результати порівняні з експериментальними даними, отриманими методом голографічної інтерферометрії.

Метод голографічної інтерферометрії широко застосовується багатьма дослідниками завдяки можливості безконтактно, з точністю реєстрації до півхвилі, визначати амплітуди коливань, візуально спостерігати виникнення переміщень та деформування конструкції при статичному та динамічному навантаженні. У [13] на основі оптичного методу голографічної інтерферометрії досліджені частоти і форми вільних коливань квадратної пластини з вільними краями. Даний метод широко використовується при дослідженні динамічних характеристик оболонок різних конфігурацій $[3,8,11]$ і показує хорошу збіжність з чисельно розрахованими частотами за допомогою методу скінченних елементів [4, 11], що підтверджує доцільність використання обох методів.

Дослідження динаміки квадратних пластин залишається актуальною темою, про що свідчить наявність сучасних публікацій. Так, в [1] наводиться огляд робіт, присвячених обчисленню частот вільних коливань прямокутної пластини та результати обчислювальних експериментів. У [6] побудовано два типи аналітичних розв'язків задачі про поперечні коливання затисненої по контуру тонкої квадратної однорідної пластини. У [10] розраховані частоти власних коливань анізотропних прямокутних пластин різної товщини з різними граничними умовами. У [12] досліджуються ортотропні прямокутні пластини змінної товщини на основі методів сплайн-апроксимації і дискретної ортогоналізації у поєднанні з методом покрокового пошуку. У [5] на основі методу суперпозиції розв'язування класичної задачі про коливання пластини з вільними краями зведено до однорідної квазірегулярної нескінченної системи лінійних алгебричних рівнянь. За допомогою достатньої умови існування обмеженого розв'язку для квазірегулярної системи знайдені власні частоти коливань пластини. У [2] досліджується тонка квадратна пластина 3 різними фізико-механічними характеристиками з вільними краями за допомогою програми FEMAP. Проводиться порівняльний аналіз розрахованих власних частот квадратної пластини з частотами, які отриманні чисельно та експериментально іншими авторами.

Методика проведення некласичного експерименту Хладні. Методику проведення класичного експерименту Хладні (рис. 1) можна описати наступним чином:

1. Затиснути центр металевої або скляної квадратної тонкої пластини в спеціальному затискному пристрої.

2. Розмістити пластину горизонтально.

3. Посипати поверхню пластини дрібним піском.

4. Торкнутися точки посередині однієї з вільних сторін пластини, організовуючи початок вузлової лінії.

5. Провести смичком по протилежному краю ближче до одного з кутів, збуджуючи коливання в пластині.

В результаті коливання поверхні пластини пісок буде збиратися вздовж вузлових ліній, при зміні вузлової лінії і точки збудження можна отримати різні рисунки Хладні, або фрорми вільних коливань пластини (рис. 2). 
Оскільки дана методика застосовується до квадратних пластин з вільними краями, то $є$ необхідним поширити і вдосконалити методику проведення експерименту до дослідження квадратних пластин з жорстко закріпленими торцями з використанням сучасної техніки.

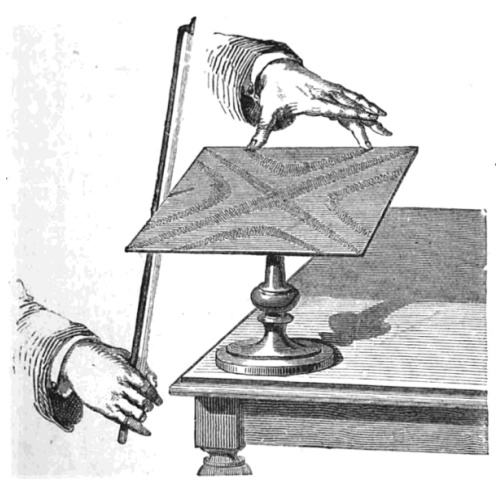

Рис. 1 - Демонстрація класичного експерименту Хладні

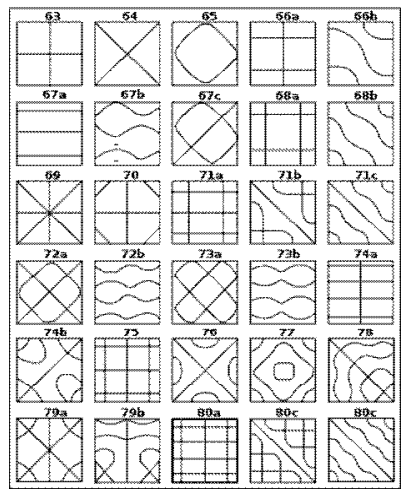

Рис. 2 - Набір фігур Хладні

Для реалізації некласичного експерименту Хладні використовувався спеціально зібраний п'єзокерамічний вібратор (рис. 3), який представляє собою суцільний стакан (3) із набором п'єзокерамічних круглих шайб (14 штук) із титанату барію з контактними пластинками із мідної тонкої фольги (2), з'єднаних паралельно, що забезпечують подачу на шайби змінної напруги. Стовпчик шайб притискується інерційним елементом (1) за допомогою різьбового з'єднання. Віброприскорення такого віброзбудження можуть досягати великих значень, які недосяжні іншими типами вібраторів.
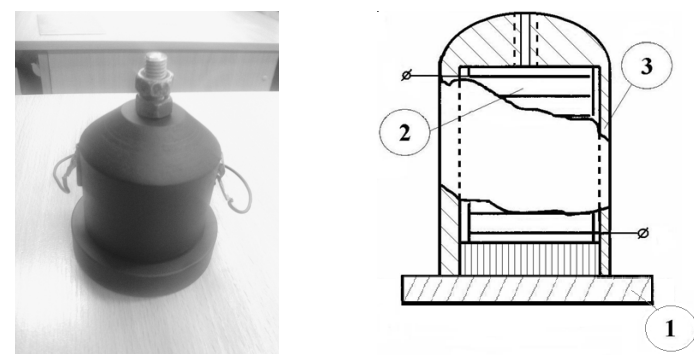

Рис. 3 - П'єзокерамічний вібратор

Експериментальне дослідження поділено на наступні етапи:

1. Зібрати віброкомплекс: віброзбуджувач, підсилювач, генератор частот, частотомір.

2. Закріпити пластину в затискній рамці.

3. Розмістити пластину горизонтально.

4. Забезпечити контакт пластини з віброзбуджувачем. 
5. Рівномірно покрити поверхню пластини сфреричними дрібними легкими елементами.

6. Включити віброкомплекс.

7. Зафріксувати форми коливань збудженої пластини у вигляді рисунків Хладні на відповідних власних частотах за допомогою цифрової фоотокамери.

Вихідні співвідношення задач динаміки МСE. Рівняння руху в МСЕ за відсутності демпфування має вигляд

$$
\mathbf{K} \vec{\Phi}_{j}+\mathbf{M} \ddot{\vec{\Phi}}_{j}=0,
$$

де $\mathbf{K}$ та $\mathbf{M}$ - матриця жорсткості та матриця мас механічної системи відповідно; $\vec{\Phi}_{j}$ - вектор переміщень вузлів системи, що відповідає j-му ступеню вільності, який відтворює $j$-ту форму коливань.

При вільних коливаннях пластини всі вузлові точки здійснюють гармонічні коливання як функції часу:

$$
\vec{\Phi}_{j}(t)=\vec{\Phi}_{j} \sin \omega_{j} t
$$

Після підстановки фрункцій (2) в рівняння руху визначення власних частот і форм коливань зводиться до розв'язання системи алгебраїчних рівнянь

$$
\mathbf{K} \vec{\Phi}_{j}-\omega_{j}^{2} \mathbf{M} \vec{\Phi}_{j}=0, \quad j=1,2, \ldots, s,
$$

де $\omega_{j}-$ пульсація або частота гармонічних коливань.

Результати досліджень. Для експериментального дослідження поставленої задачі була виготовлена алюмінієва (модуль Юнга $E=71$ ГПа , коефіцієнт Пуассона $v=0,34$, густина $\left.\rho=2710 \kappa 2 / \mathrm{m}^{3}\right)$ тонка квадратна пластина сталої товщини $d=3$ мм розміром $a=140$ мм . Для забезпечення жорсткого закріплення торців пластини виготовлено спеціальну затискну сталеву рамку (рис. 4).

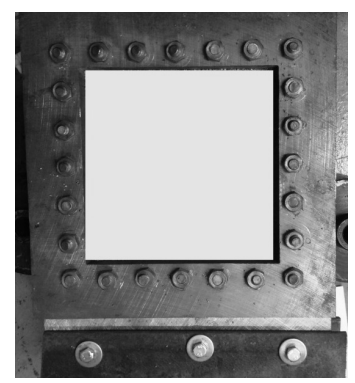

Рис. 4 - Експериментально досліджувана пластини

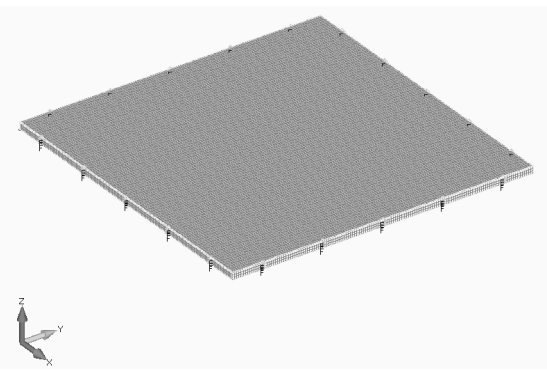

Рис. 5 - Скінченно-елементна модель пластини 
Для числового розрахунку було створено скінченноелементну модель пластини (рис. 5) відповідно до розмірів, фрізико-механічних характеристик і граничних умов експериментально дослідженої пластини. Розбиття області проводилась plate-елементами розмірами 1 мм $\times 1$ мм .

Результати експериментально та числового визначених частот вільних коливань представленні у табл. 1 , де $\varepsilon-$ відхилення між числовими та експериментально отриманими частотами.

Таблиця 1 - Порівняння експериментально та чисельно отриманих частот

\begin{tabular}{|c|c|c|c|}
\hline \multirow{2}{*}{ Moda } & \multicolumn{2}{|c|}{$\omega, \Gamma$ } & \multirow{2}{*}{$\varepsilon, \%$} \\
\cline { 2 - 3 } & Хладні & FEMAP & \\
\hline 2 & 2559 & 2789,16 & 8,99 \\
\hline 3 & 2553 & 2789,16 & 9,25 \\
\hline 4 & 3765 & 4095,74 & 8,78 \\
\hline 5 & 4522 & 4971,83 & 9,95 \\
\hline 6 & 5544 & 4997,01 & 9,87 \\
\hline
\end{tabular}

Форми коливань представлені на рис. 6, рис. 7.

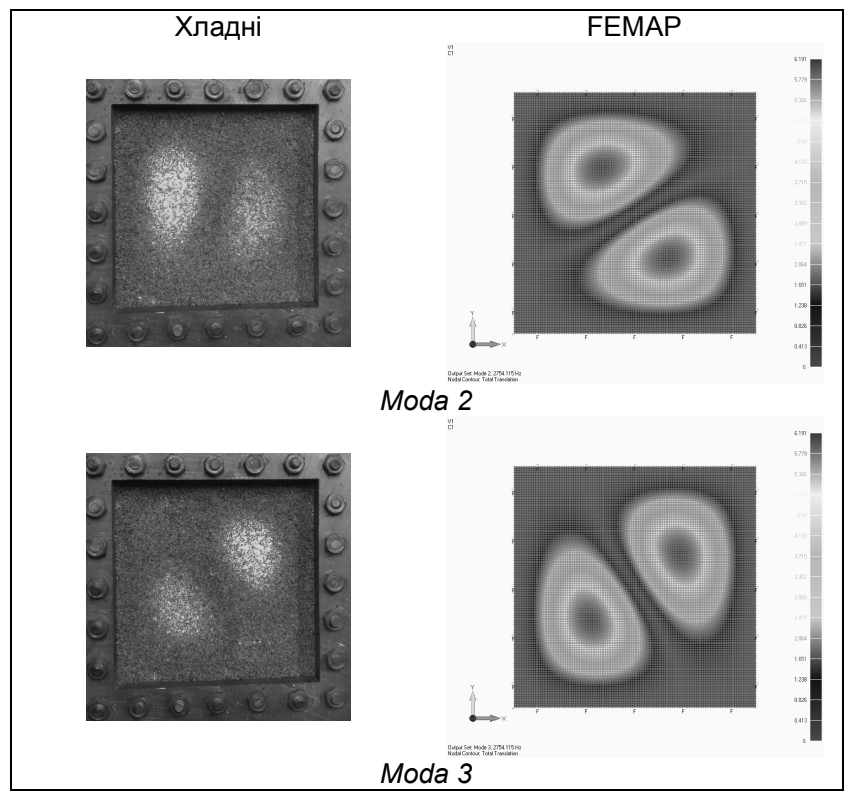

Рис. 6 - Форми коливань пластини

Висновки. Здійснено дослідження вільних коливань тонкої ізотропної жорстко закріпленої квадратної пластини за допомогою розробленої методики проведення некласичного експерименту Хладні та MCE, peaлізованого на FEMAP. 


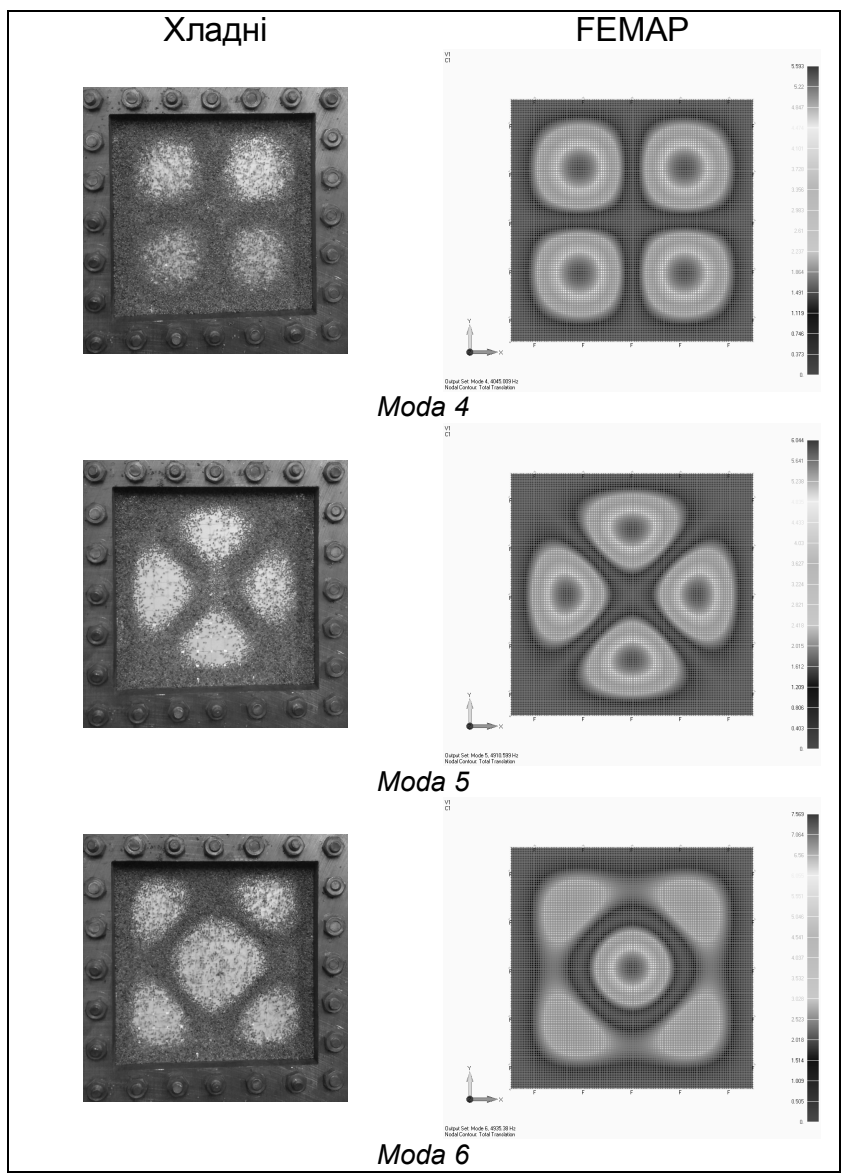

Рис. 7 - Форми коливань пластини

Результати експериментальних досліджень вільних коливань пластин добре узгоджуються з чисельними розрахунками, що свідчить про ефективність застосування обох підходів.

Розроблена експериментальна установка може бути використана для демонстрації розповсюдження механічних хвиль в плоских конструкціях.

\section{БІБЛІОГРАФІЧНІ ПОСИЛАННЯ}

1. Алгазин С. Д. Вычислительный эксперимент в задаче о свободных колебаниях прямоугольной пластины // Наука и техника транспорта. 2016. № 4. C. 100-107.

2. Борисенко М. Ю., Бойчук О. В., Борисенко І. А., Роговцов Ю. О. Комп'ютерне моделювання вільних коливань тонких пластин з різних матеріалів // Геометричне моделювання та інформаційні технології. Миколаїв, 2016. № 2. С. 29-33.

3. Будак В. Д., Григоренко О. Я., Борисенко М. Ю., Пригода О. П., Бойчук О. В. 
Визначення власних частот тонкостінної оболонки некругового поперечного перерізу методом стробоголографічної інтерферометрі //. Пробл. обчислюв.ї механіки і міцності конструкцій: зб. наук. праць. Д.: Ліра. 2015. Вип. 24. С. 18-25.

4. Будак В. Д., Григоренко О. Я., Борисенко М. Ю., Бойчук О. В. Вплив ексцентриситету еліптичної оболонки на розподіл її динамічних характеристик // Вісник Київського нац.. ун-ту ім. Тараса Шевченка. Фіз.-мат. науки. 2015. Вип. 1. С. 23-28.

5. Мелешко В. В., Папков С. О. Изгибные колебания упругих прямоугольных пластин со свободными краями: от Хладни (1809) и Ритца (1990) до наших дней // Акустичний вісник. К. 2009. Т. 12. № 4. С. 34-51.

6. Нестеров С. В. Изгибные колебания квадратной пластины, защемленной по контуру // Механика твердого тела. 2011. № 6. С. 159-165.

7. Рудаков К. Н. FEMAP 10.2.0. Геометрическое и конечно-элементное моделирование конструкций. К.: НТУУ «КПИ», 2011. 317 с.

8. Budak V. D., Grigorenko A. Ya., Khorishko V. V., Borisenko M. Yu. Holographic Interferometry Study of the Free Vibrations of Cylindrical Shells of Constant and Variable Thickness // International Applied Mechanics. 2014. Vol. 50. N 1. P. 68-74.

9. Grigorenko A. Ya., Tregubenko T. V. Numerical and experimental analysis of natural vibrations of rectangular plates with variable thickness // International Applied Mechanics. 2000. Vol. 36. № 2. P. 268-270.

10. Grigorenko A. Ya., Borisenko M. Yu., Boichuk E. V., Prigoda A .P. Numerical Determination of Natural Frequencies and Modes of the Vibrations of a Thick-Walled Cylindrical Shell // International Applied Mechanics. 2018. Vol. 54. No 1. P. 75-84.

11. Grigorenko A. Ya., Efimova T. L. Spline-approximation method applied to solve natural-vibration problems for rectangular plates of varying thickness // International Applied Mechanics. 2005. Vol. 41. No 10. P. 1161-1169.

12. Grigorenko Ya. M., Grigorenko A. Ya., Efimova T. L. Spline-based investigation of natural vibrations of orthotropic rectangular plates of variable thickness within classical and refined theories // Journal of mechanics of materials and structures. 2008. Vol. 3. No. 5. P. 929-952.

13. Ma C.-C., Huang C.-H. Experimental whole-field interferometry for transverse vibration of plates // Journal of Sound and Vibration. 2004. Vol. 271. P. 493-506.

УДК 539.3

\author{
${ }^{1}$ А. Я. Григоренко, д-р фоиз.-мат. наук, \\ ${ }^{1}$ М. Ю. Борисенко, канд. фоз.-мат. наук, \\ ${ }^{2}$ E. В. Бойчук, канд. фоиз.-мат. наук, ${ }^{3}$ В. С. Новицкий
}

\title{
ПРИМЕНЕНИЕ ЭКСПЕРИМЕНТАЛЬНОГО И ЧИСЛЕННОГО МЕТОДОВ К ИССЛЕДОВАНИЮ СВОБОДНЫХ КОЛЕБАНИЙ ПРЯМОУГОЛЬНЫХ ПЛАСТИН
}

\footnotetext{
Исследуются динамические характеристики тонкой изотропной жестко закрепленной квадратной пластины посредством реализации неклассического эксперимента Хладни и метода конечных элементов, реализованного на лицензионном программном комплексе FEMAP. Описывается методика проведения эксперимента и численного расчета. Проводится сравнительный анализ полученных результатов экспериментальных и численных исследований.

Ключевые слова: квадратная пластина, свободные колебания, фрормы колебаний, эксперимент Хладни, метод конечных элементов.
} 


\author{
${ }^{1}$ A. Ya. Grigorenko, Dr. Sci. (Phys.-Math.), \\ ${ }^{1}$ M. Yu. Borysenko, PhD. (Phys.-Math.), \\ ${ }^{2}$ O. V. Boychuk, PhD. (Phys.-Math.), ${ }^{3}$ V. S. Novytskyi
}

\title{
APPLICATION OF EXPERIMENTAL AND NUMERICAL METHODS TO THE STUDY OF FREE OSCILLATIONS OF RECTANGULAR PLATES
}

The dynamic characteristics of a thin isotropic rigidly fixed square plate are investigated by means of the implementation of the non-classical Chladni experiment and the finite element method implemented on the FEMAP licensed software package. The technique of the experiment and numerical calculation are described. A comparative analysis of the results of experimental and numerical is carried out.

Keywords: square plate, free oscillations, vibration shapes, Chladni experiment, finite element method.

Introduction. In various branches of modern technology the plates of various shapes are the most common elements of thin-walled structures. It is necessary to have information about the dynamic characteristics of such structures and mechanisms to assess the strength and ensure their reliable operation.

The purpose of this paper is determination of free oscillations frequencies and forms of an elastic isotropic rigidly fixed square plate using the nonclassical Chladni experiment and comparison of the results obtained with the calculations performed by the finite element method.

Technique of non-classical experiment.

1. Assemble the vibration complex: vibration exciter, amplifier, frequency generator, frequency meter.

2. Fix the plate in the clamping frame.

3. Place the plate horizontally.

4. Ensure the contact of the plate with the vibrator exciter.

5. Distribute spherical small lightweight elements on the plate surface evenly.

6. Turn on the vibrocomplex.

7. Fix the vibration forms of the excited plate in the form of Chladni's drawings at their respective natural frequencies using a digital camera.

Results of investigations. An aluminium thin square plate of constant thickness was made for an experimental study.

The finite element model of the plate for the numerical calculation was created in accordance with the dimensions, physical-mechanical characteristics and boundary conditions of the experimentally investigated plate.

The results of experimental and numerically determined free oscillation frequencies are presented in Table 1 , where $\varepsilon$ is the deviation between the numerical and experimentally obtained frequencies. 
Table 1 - Comparison of experimental and numerically received frequencies

\begin{tabular}{|c|c|c|c|}
\hline \multirow{2}{*}{ Moda } & \multicolumn{2}{|c|}{$\omega, \mathrm{Hz}$} & \multirow{2}{*}{$\varepsilon, \%$} \\
\cline { 2 - 3 } & Chladni & FEMAP & \\
\hline 2 & 2559 & 2789,16 & 8,99 \\
\hline 3 & 2553 & 2789,16 & 9,25 \\
\hline 4 & 3765 & 4095,74 & 8,78 \\
\hline 5 & 4522 & 4971,83 & 9,95 \\
\hline 6 & 5544 & 4997,01 & 9,87 \\
\hline
\end{tabular}

Conclusions. The study of free oscillations of a thin isotropic rigidly fixed square plate was carried out using the developed methodology for conducting the non-classical Chladni experiment and FEM implemented on FEMAP.

The results of the experimental study are in good agreement with numerical calculations, which indicates the effectiveness of the use of both approaches.

An experimental installation can be used to demonstrate the propagation of mechanical waves in flat structures.

\section{REFERENCES}

1. Alhazyn S. D. Computational experiment in the problem of free oscillations of a rectangular plate // Nauka i tehnika transporta. 2016. No 4. P. 100-107. (in Russian).

2. Borisenko M. Yu., Boychuk O. V., Borisenko I. A., Rogovtsov, Yu. O. Computer modeling of free vibrations of thin plates with different materials // Geometric modeling and information technologies, Mykolaiv, 2016. No 2. P. 29-33. (in Ukrainian).

3. Budak V. D., Grigorenko A. Ya., Borisenko M. Yu., Prigoda A. P., Boychuk O. V. Determination of the natural frequencies of thin-walled shells with non-circular crosssection using the method of stroboholographic interferometry // Problems of computational mechanics and strength of structures. Dnipropetrovsk: Lira. 2015. No 24. P. 18-25. (in Ukrainian).

4. Budak V. D., Grigorenko A. Ya., Borisenko M. Yu., Boychuk O. V. The elliptical shell eccentricity impact on the distribution of its dynamic characteristics // Bulletin of Taras Shevchenko National University of Kyiv. Ser.: Physics \& Mathematics. 2015. No 1. P. 2328. (in Ukrainian).

5. Meleshko V. V., Papkov S. O. Flexural vibration of elastic rectangular plates with free edges: from Chladni (1809) and Ritz (1990) to the present day // Akustychnyi visnyk. Kyiv. 2009. Vol. 12. No 4. P. 34-51. (in Russian).

6. Nesterov S. V. Flexural vibration of a square plate clamped along its contour // Mechanics of Solids. 2011. No 6. P. 159-165. (in Russian).

7. Rudakov K. N. FEMAP 10.2.0. The Geometric and finite-element modeling of structures. Kiïv: NTUU «KPI», 2011. 317 p. (in Russian).

8. Budak V. D., Grigorenko A. Ya., Khorishko V. V., Borisenko M. Yu. Holographic Interferometry Study of the Free Vibrations of Cylindrical Shells of Constant and Variable Thickness // International Applied Mechanics. 2014. Vol. 50. No 1. P. 68-74.

9. Grigorenko A. Ya., Tregubenko T. V. Numerical and experimental analysis of natural vibrations of rectangular plates with variable thickness // International Applied Mechanics. 2000. Vol. 36. No 2. P. 268-270.

10. Grigorenko A. Ya., Borisenko M. Yu., Boichuk E. V., Prigoda A .P. Numerical Determination of Natural Frequencies and Modes of the Vibrations of a Thick-Walled Cylindrical Shell // International Applied Mechanics. 2018. Vol. 54. No 1. P. 75-84.

11. Grigorenko A. Ya., Efimova T. L. Spline-approximation method applied to solve natural-vibration problems for rectangular plates of varying thickness // International 
Applied Mechanics. 2005. Vol. 41. No 10. P. 1161-1169.

12. Grigorenko Ya. M., Grigorenko A. Ya., Efimova T. L. Spline-based investigation of natural vibrations of orthotropic rectangular plates of variable thickness within classical and refined theories // Journal of mechanics of materials and structures. 2008. Vol. 3. No. 5. P. 929-952.

13. Ma C.-C., Huang C.-H. Experimental whole-field interferometry for transverse vibration of plates // Journal of Sound and Vibration. 2004. Vol. 271. P. 493-506.

Друкується за рекомендацією програмного комітету Міжнародної науковотехнічної конфреренції «Математичні проблеми технічної механіки та прикладної математики - 2019». м. Кам'янське.

${ }^{1}$ Інститут механіки ім. С.П. Тимошенко

НАН України,

Київ, Україна

${ }^{2}$ Миколаївський національний аграрний

університет,

Миколаїв, Україна

${ }^{3}$ Миколаївський муніципальний колегіум

ім. В. Д. Чайки,

Миколаїв, Україна

Надійшла до редколегії 02.03.2019 